\title{
Activity of the hippocampal somatostatinergic system following daily administration of melatonin
}

\author{
Rosa María Izquierdo-Claros, María del Carmen Boyano-Adánez, Eduardo Arilla-Ferreiro* \\ Departamento de Bioquímica y Biología Molecular, Facultad de Medicina, Grupo de Neurobioquímica, Ctra. Madrid-Barcelona Km. 33,600, \\ Universidad de Alcalá, E-28871 Alcalá de Henares, Madrid, Spain
}

Accepted 26 March 2004

Available online 4 May 2004

\begin{abstract}
If melatonin or its analogs are to be used therapeutically in humans, their chronic effects on responsiveness of melatonin target cells need to be assessed. We have previously demonstrated that acute melatonin treatment regulates the somatostatinergic system in the rat hippocampus. In the present study, we have investigated the effects of subchronic and chronic daily treatment with melatonin on the somatostatinergic system in the rat hippocampus. Male Wistar rats $(200-250 \mathrm{~g})$ were injected with melatonin $(25 \mu \mathrm{g} / \mathrm{kg}$ body weight, subcutaneously) daily for 4,7 or 14 days and sacrificed $24 \mathrm{~h}$ after the last injection. Melatonin administration for 4 days induced a decrease in the hippocampal somatostatin (SRIF)-like immunoreactivity content as well as a decrease in the number of SRIF receptors and an increase in their apparent affinity. The decreased number of SRIF receptors in the melatonin (4 days)-treated rats was associated with a decreased capacity of SRIF to inhibit both basal and forskolin-stimulated adenylyl cyclase activity. These melatonin-induced effects reversed to control values after 7 or 14 days of treatment. Hippocampal membranes from control and melatonin-treated rats showed similar Gi and Gs activities.

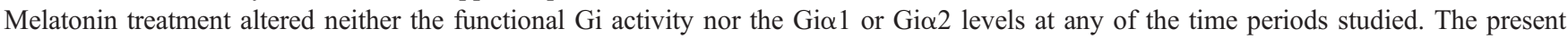
results suggest that chronic exposure to melatonin results in a tolerance of the hippocampus to this hormone.
\end{abstract}

(C) 2004 Elsevier B.V. All rights reserved.

Theme: Neurotransmitters, modulators, transporters and receptors

Topic: Receptor modulation, up- and down-regulation

Keywords: Somatostatin receptors; Melatonin; Adenylyl cyclase; G proteins; Hippocampus; Rat

\section{Introduction}

In mammals, melatonin ( $N$-acetyl-5-methoxytryptamine) is mainly produced by the pineal gland [3] and, to some extent, by other extrapineal tissues such as the retina and gastrointestinal tract [34]. It is involved in regulating neuroendocrine function and acts directly on the biological clock in the suprachiasmatic nucleus to modulate the circadian rhytmicity of diverse biological functions such as sleep, hormonal and temperature cycles $[42,43]$. To date, only the Mella and Mel1b receptors have been detected in mammals [43]. Some of the responses of melatonin have been reported to be mediated through GABA-benzodiazepine receptors in the central nervous system [23]. In addition, 85

* Corresponding author. Tel.: +34-91-885-45-09; fax: +34-91-885-45-

E-mail address: carmen.boyano@uah.es (E. Arilla-Ferreiro). melatonin is known to possess free radical scavenging and antioxidant properties [35]. There is increasing interest in the clinical applications of melatonin as therapeutic agents in humans [4]. If melatonin or its analogs are to be used therapeutically in humans, the effects of chronic exposure to these antagonists on the responsiveness of melatonin target cells need to be assessed. However, the functional consequence of chronic melatonin treatment has received little attention, and it is unknown whether such a treatment can subsequently alter the sensitivity of different brain areas to melatonin. Previous studies carried out by our group have demonstrated that acute melatonin treatment regulates the rat hippocampal somatostatinergic system in vivo [19]. In the present study, we have investigated the effects of subchronic and chronic daily melatonin administration on somatostatin (SRIF)-like immunoreactivity (SRIF-LI) levels and on $\left[{ }^{125} \mathrm{I}\right]-\mathrm{Tyr}^{11}$-SRIF binding to its specific receptors in the rat hippocampus. We have also evaluated the effect of melatonin on SRIF-mediated inhibition of adenylyl cyclase 
(AC) activity in the rat hippocampus. In addition, the AC catalytic subunit was measured by stimulating the enzyme with the diterpene forskolin. The functional activity of Gi proteins was also determined.

\section{Materials and methods}

\subsection{Chemicals and reagents}

Melatonin, phenylmethylsulfonyl fluoride (PMSF), 3isobutyl-1-methylxanthine (IBMX), bovine serum albumin (fraction V) (BSA), guanosine triphosphate (GTP), forskolin, pre-stained protein markers and other reagents for sodium dodecylsulfate-polyacrylamide gel electrophoresis (SDS/PAGE) were purchased from Sigma (Madrid, Spain). Specific antiserum against ail (MAB3075) or ai2 (MAB3077) G protein subunits was obtained from Chemicon International (California, USA). Nitrocellulose membranes as well as the chemiluminescence Western blotting detection system were purchased from Amersham (Buckinghamshire, UK). All other reagents were of the highest purity commercially available.

\subsection{Experimental animals}

All procedures regarding handling and treatment of laboratory animals were carried out in accordance to the guidelines established by our Animal Care and Use Committee and were approved by the mentioned Committee before implementation. Efforts were made to minimize animal's suffering and to use only the exact number of animals necessary to secure reliable scientific data. In the present study, male Wistar rats weighing 200-250 g were used. All animals received food and tap water ad libitum. Room temperature was kept constant at $22{ }^{\circ} \mathrm{C}$ and 12-h day-night cycles were maintained. Melatonin was dissolved in saline containing ethanol $(0.5 \%)$ and administered subcutaneously (s.c.) at $0900 \mathrm{~h}$ in a volume of $100 \mu \mathrm{l}$ according to the method described by Alexiuk and Vriend [2] at a dose of $25 \mu \mathrm{g} / \mathrm{kg}$ [1] daily for 4,7 or 14 days. Control animals selected for each experimental group were injected with saline containing ethanol. All animals were sacrificed by decapitation $24 \mathrm{~h}$ after the last injection. The brains were removed and the hippocampus was immediately dissected as described by Glowinski and Iversen [14].

\subsection{Binding assay}

$\mathrm{Tyr}^{11}$-SRIF was radioiodinated by chloramine-T iodination according to the method of Greenwood et al. [15]. The tracer was purified in a Sephadex G-25 fine column $(1 \times 100 \mathrm{~cm})$ equilibrated with $0.1 \mathrm{M}$ acetic acid containing BSA $0.1 \%(\mathrm{w} / \mathrm{v})$. The specific activity of the purified labelled peptide was about $600 \mathrm{Ci} / \mathrm{g}$.
Hippocampal membranes were prepared as previously described by Reubi et al. [36]. Protein concentration was assayed by the method of Lowry et al. [25], with BSA as a standard. Specific SRIF binding was measured according to the modified method of Czernik and Petrack [7]. Briefly, the membranes $(0.15 \mathrm{mg}$ protein $/ \mathrm{ml})$ were incubated in $250 \mu \mathrm{l}$ of a medium containing $50 \mathrm{mM}$ Tris/ $\mathrm{HCl}$ buffer $(\mathrm{pH} 7.5), 5$ $\mathrm{mM} \mathrm{MgCl}, 0.2 \%(\mathrm{w} / \mathrm{v}) \mathrm{BSA}$ and $0.1 \mathrm{mg} / \mathrm{ml}$ bacitracin with $250 \mathrm{pM}\left[{ }^{125} \mathrm{I}\right]$-Tyr ${ }^{11}$-SRIF either in the absence or presence of 0.01-10 nM unlabelled SRIF. After a 60-min incubation at $30{ }^{\circ} \mathrm{C}$, bound and free ligand were separated by centrifugation at $11,000 \times g$ for $2 \mathrm{~min}$. The supernatant was discarded and the pellet was washed with Tris $(50 \mathrm{mM})-$ sacarose $(0.9 \%)$ buffer $(\mathrm{pH} 7.4)$. The radioactivity in the pellet was measured in a Kontron gamma counter. Nonspecific binding was obtained from the amount of radioactivity bound in the presence of $10^{-7} \mathrm{M}$ SRIF and represented about $20 \%$ of the binding observed in the absence of unlabelled peptide. This nonspecific component was subtracted from the total bound radioactivity in order to obtain the corresponding specific binding.

\subsection{Evaluation of radiolabelled peptide degradation}

The inactivation of $\left[{ }^{125} \mathrm{I}\right]-\mathrm{Tyr}{ }^{11}$-SRIF in the incubation medium after exposure to membranes was studied by measuring the ability of preincubated peptide to rebind to fresh membranes. Briefly, $\left.{ }^{125} \mathrm{I}\right]-\mathrm{Tyr}^{11}$-SRIF $(250 \mathrm{pM})$ was incubated with membranes from rat hippocampus $(0.15 \mathrm{mg}$ protein $/ \mathrm{ml}$ ) for $60 \mathrm{~min}$ at $30{ }^{\circ} \mathrm{C}$. After this preincubation, aliquots of the medium were added to fresh membranes and incubated for an additional $60 \mathrm{~min}$ at $30{ }^{\circ} \mathrm{C}$. The fraction of the added radiolabelled peptide which was specifically bound during the second incubation was measured and expressed as a percentage of the binding that had been obtained in control experiments performed in the absence of membranes during the preincubation period.

\subsection{Tissue extraction and somatostatin radioimmunoassay}

For measurements of SRIF-LI content, the hippocampus was rapidly homogenized in $1 \mathrm{ml}$ of $2 \mathrm{M}$ acetic acid using a Brinkman polytron (setting 5,30 s). Extracts were boiled for $5 \mathrm{~min}$ in a water bath and chilled on ice. Subsequently, homogenates were centrifuged at $15,000 \times \mathrm{g}$ for $15 \mathrm{~min}$ at 4 ${ }^{\circ} \mathrm{C}$. The pellet was discarded and $25 \mu \mathrm{l}$ of the supernatant were taken for protein analysis [25]. Extracts were immediately stored at $-80{ }^{\circ} \mathrm{C}$ until assay. The immunoreactivity content was determined in tissue extracts by a modified radioimmunoassay method [31], with a sensitivity limit of $10 \mathrm{pg} / \mathrm{ml}$. The possibility that substances present in the tissue extracts might interfere with antibody-antigen binding and give rise to erroneous results was checked by performing serial dilutions of selected extracts in the assays and comparing the resulting changes in SRIF-LI with those of the diluted standards. In addition, known standard 
amounts of the hormone were added to varying amounts of the extracts and serial dilutions were again assayed, in order to determine if this exogenously added hormonal immunoreactivity could be measured reliably in the presence of tissue extracts. Incubation tubes prepared in duplicate contained $100 \mu \mathrm{l}$ samples of unknown or standard solutions of $0-500 \mathrm{pg}$ cyclic SRIF tetradecapeptide, diluted in phosphate buffer $(0.1 \mathrm{M}, \mathrm{pH} 7.2$ containing $0.2 \%$ BSA, $0.1 \%$ sodium azide), $200 \mu \mathrm{l}$ of appropriately diluted antiSRIF serum, $100 \mu \mathrm{l}$ of freshly prepared $\left[{ }^{125} \mathrm{I}\right]-\mathrm{Tyr}^{11}$-SRIF, diluted in buffer to yield 6000-10000 cpm (equivalent to $5-10 \mathrm{pg}$ ), and enough buffer to give a final volume of 0.8 $\mathrm{ml}$. All reagents, as well as the assay tubes, were kept chilled in ice before incubation at $4{ }^{\circ} \mathrm{C}$ for $24 \mathrm{~h}$. Separation of bound and free hormone was accomplished by addition of $1 \mathrm{ml}$ dextran-coated charcoal (dextran: $0.2 \% \mathrm{w} / \mathrm{v}$ ). Dilution curves for each brain area were parallel to the standard curve. The coefficients for intra- and inter-assay variation were $6.5 \%$ and $8.3 \%$, respectively.

\subsection{Adenylyl cyclase assay}

Hippocampal membranes were prepared as previously described by Reubi et al. [36]. Protein concentration was assayed by the method of Lowry et al. [25] with BSA as a standard. AC activity was measured as previously described [18], with some minor modifications. Briefly, hippocampal membranes $(0.06 \mathrm{mg} / \mathrm{ml})$ were incubated with $1.5 \mathrm{mM}$ ATP, $5 \mathrm{mM} \mathrm{MgSO} 4,10 \mu \mathrm{M}$ GTP, an ATP-regenerating system (7.5 $\mathrm{mg} / \mathrm{ml}$ creatine phosphate and $1 \mathrm{mg} / \mathrm{ml}$ creatine kinase), $1 \mathrm{mM}$ IBMX, $0.1 \mathrm{mM}$ PMSF, $1 \mathrm{mg} / \mathrm{ml}$ bacitracin, $1 \mathrm{mM}$ EDTA, and test substances $\left(10^{-4} \mathrm{M}\right.$ SRIF or $10^{-5} \mathrm{M}$ forskolin) in $0.1 \mathrm{ml}$ of $0.025 \mathrm{M}$ triethanolamine/ $\mathrm{HCl}$ buffer (pH 7.4). After a 15 -min incubation at $30{ }^{\circ} \mathrm{C}$, the reaction was stopped by heating the mixture at $100{ }^{\circ} \mathrm{C}$ for $3 \mathrm{~min}$. Once cooled, $0.2 \mathrm{ml}$ of an aluminum slurry $(0.75 \mathrm{~g} / \mathrm{ml}$ in triethanolamine/ $\mathrm{HCl}$ buffer, $\mathrm{pH}$ 7.4) was added and the suspension was centrifuged. The supernatant was then removed for assay of cyclic AMP (cAMP) by the method described by Gilman [12]. The SRIF concentration used was that deemed necessary to achieve inhibition of rat [39] AC activity. Similarly, forskolin was used at a concentration that could effectively stimulate the catalytic subunit of rat AC [39].

\subsection{Immunodetection of $G$ protein $\alpha i$ subunits}

Membranes $(100 \mu \mathrm{g})$ were solubilized in SDS-sample buffer and the resulting proteins were then run on a $12 \%$ SDS-polyacrylamide gel as described by Laemmli [21]. After separation, the proteins were transferred onto nitrocellulose membranes in a buffer consisting of $25 \mathrm{mM}$ Tris/ $\mathrm{HCl}, \mathrm{pH} 8.3,192 \mathrm{mM}$ glycine, 20\% methanol and $0.05 \%$ SDS. The transferred nitrocellulose membranes were blocked with TTBS $(50 \mathrm{mM}$ Tris/HCl, $\mathrm{pH} 7.5,150 \mathrm{mM}$ $\mathrm{NaCl}$, and $0.05 \%$ Tween-20) containing $5 \%(\mathrm{w} / \mathrm{v})$ non-fat dry milk during $1.5 \mathrm{~h}$ at $4{ }^{\circ} \mathrm{C}$. Nitrocellulose membranes were subsequently immunoblotted with anti-Gi 1 or antiGi 2 monoclonal antibodies (1:1000 dilution) in TTBS and incubated overnight at $4{ }^{\circ} \mathrm{C}$. After incubation, three 5-min washes in TTBS containing $5 \%(\mathrm{w} / \mathrm{v})$ non-fat dry milk were carried out. A mouse $\operatorname{IgG}$-peroxidase conjugate (1:2000 dilution) in TTBS was then added to the membranes and incubated for $1 \mathrm{~h}$ at $4{ }^{\circ} \mathrm{C}$. After washing, the bound immunoreactive proteins were detected by a chemiluminescent (ECL) Western blotting detection system.

\subsection{Data analysis}

Statistical comparisons of all the data were carried out by one-way analysis of variance (ANOVA) and the StudentNewman-Keuls test. Means among groups were considered significantly different when the $p$ values were less than 0.05 . Each experiment was performed in duplicate.

\section{Results}

Preliminary experiments confirmed that the specific binding of $\left[{ }^{125} \mathrm{I}\right]$-Tyr ${ }^{11}$-SRIF to hippocampal membranes changed linearly with protein concentration and was timedependent in all experimental groups. An apparent equilibrium was observed between 50 and $180 \mathrm{~min}$ at $30{ }^{\circ} \mathrm{C}$ (data not shown). All subsequent binding experiments were therefore conducted at $30{ }^{\circ} \mathrm{C}$ for $60 \mathrm{~min}$. Our group [20] has studied the specific binding of $\left[{ }^{125} \mathrm{I}\right]-\mathrm{Tyr}^{11}$-SRIF to hippocampal membranes in rats treated with $10,25,50$ or $100 \mu \mathrm{g} /$ $\mathrm{kg}$, s.c., of melatonin. The doses of 10 and $25 \mu \mathrm{g} / \mathrm{kg}$ significantly decreased the specific binding of $\left[{ }^{125} \mathrm{I}\right]-\mathrm{Tyr}^{11}$ SRIF to rat hippocampal membranes as compared to the control group, with no changes being observed at the higher doses. Since the maximal effect of melatonin on SRIF receptors was detected at the dose of $25 \mu \mathrm{g} / \mathrm{kg}$, subsequent studies were carried out at this dose. Stoichiometric experiments were performed on rat hippocampal membranes using

Table 1

Effect of melatonin at a daily dose of $25 \mu \mathrm{g} / \mathrm{kg}$ s.c. during 4,7 or 14 days on the equilibrium parameters for $\left[{ }^{125} \mathrm{I}\right]-\mathrm{Tyr}^{11}$-SRIF binding to rat hippocampal membranes

\begin{tabular}{lll}
\hline & \multicolumn{2}{l}{ SRIF receptors } \\
\cline { 2 - 3 } & $B_{\max }$ & $K_{\mathrm{d}}$ \\
\hline Control & $543 \pm 12$ & $0.51 \pm 0.04$ \\
Melatonin 4 days & $399 \pm 23^{* * *}$ & $0.35 \pm 0.04 *$ \\
Control & $478 \pm 9$ & $0.48 \pm 0.02$ \\
Melatonin 7 days & $456 \pm 12$ & $0.52 \pm 0.03$ \\
Control & $488 \pm 10$ & $0.40 \pm 0.02$ \\
Melatonin 14 days & $476 \pm 30$ & $0.39 \pm 0.01$ \\
\hline
\end{tabular}

Binding parameters were calculated from Scatchard plots by linear regression. Units for $K_{\mathrm{d}}$ are $\mathrm{nM}$, units for $B_{\max }$ are fmol of SRIF bound per $\mathrm{mg}$ of protein. The results are represented as the mean \pm S.E.M. of five separate experiments, each performed in duplicate. Statistical comparison versus control: $* p<0.05 ; * * * p<0.001$. 

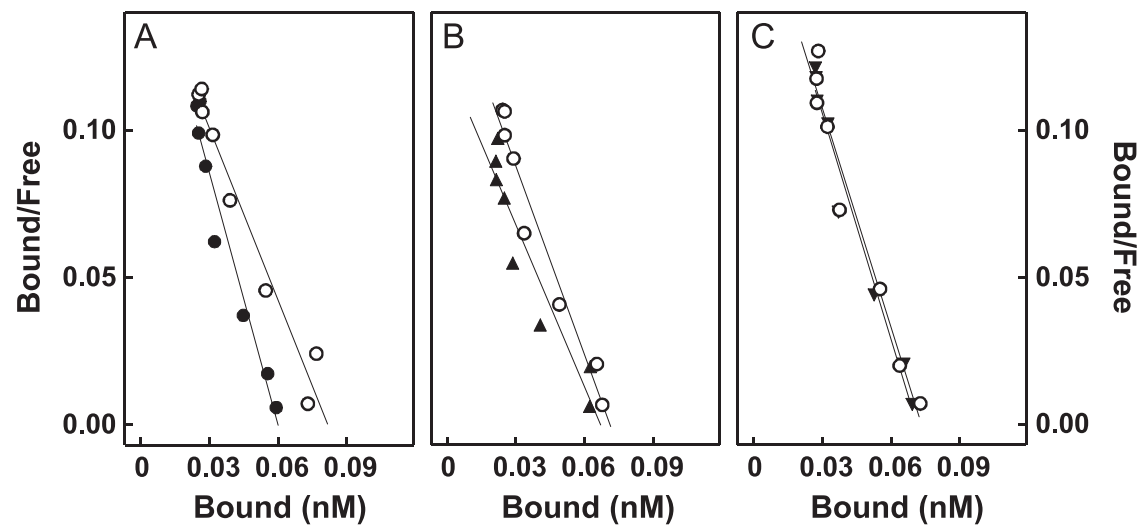

Fig. 1. Scatchard plots of the specific binding of $\left[{ }^{125} \mathrm{I}\right]-\mathrm{Tyr}^{11}$-SRIF to rat hippocampal membranes. Membranes $(0.15 \mathrm{mg}$ of protein $/ \mathrm{ml})$ were incubated for 60 min at $30{ }^{\circ} \mathrm{C}$ in the presence of $250 \mathrm{pM}\left[{ }^{125} \mathrm{I}\right]-\mathrm{Tyr}^{11}$-SRIF and increasing concentrations of SRIF. Points correspond to control rats $(\mathrm{O})$, and rats treated with melatonin for 4 days $(\bullet)(A), 7$ days $(\mathbf{\Delta})$ (B) and 14 days $(\boldsymbol{\nabla})(\mathrm{C})$. The animals were sacrificed $24 \mathrm{~h}$ after the last injection.

a fixed concentration of $\left.{ }^{125} \mathrm{I}\right]-\mathrm{Tyr}^{11}$-SRIF and increasing doses of unlabelled SRIF at $30{ }^{\circ} \mathrm{C}$ for $60 \mathrm{~min}$. Melatonin administration during 4 days produced a significant decrease in $\left[{ }^{125} \mathrm{I}\right]$-Tyr ${ }^{11}$-SRIF binding to rat hippocampal membranes as compared to controls. This decrease was due to a decrease in the maximal number of SRIF receptors as revealed by Scatchard plots of the binding data (Table 1; Fig. 1). In addition, a significant increase in the affinity of these receptors was observed (Table 1; Fig. 1). No changes in the SRIF receptor number or affinity were observed, however, at 7 or 14 days of melatonin administration (Table 1).

Daily melatonin administration for 4 days decreased SRIF-LI content in the rat hippocampus as compared with the control group (Fig. 2). No changes were

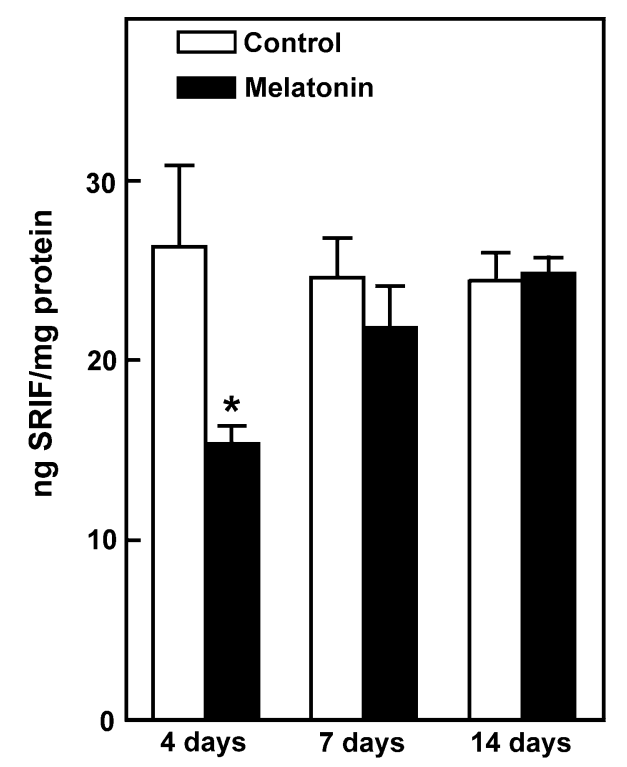

Fig. 2. Effect of melatonin $(25 \mu \mathrm{g} / \mathrm{kg})$ treatment for 4,7 or 14 days on somatostatin (SRIF)-like immunoreactivity in the rat hippocampus. Values are expressed as the mean \pm S.E.M. of five experiments, each performed in duplicate. Statistical comparison versus control: $* p<0.05$. observed after 7 or 14 days of melatonin administration (Fig. 2).

One of the signalling pathways coupled to SRIF receptors is the inhibition of AC. Therefore, in order to investigate whether the functional effect of SRIF was affected by melatonin treatment, hippocampal membranes from control and melatonin-treated rats were assayed for SRIF-induced inhibition of AC activity. In the melatonin-treated groups, the degree of SRIF inhibition of both basal and forskolinstimulated AC activity was significantly lower than in the control group after 4 days of its daily administration (Table 2). After 7 or 14 days of melatonin treatment, no significant differences were observed in this parameter (data not shown).

To test if the observed changes were related to modifications in the expression of $\mathrm{AC}$, the response of the enzyme to the diterpene forskolin $\left(10^{-5} \mathrm{M}\right)$, which is assumed to act directly upon the catalytic subunit, was measured. No significant differences were detected in the fold forskolin stimulation over basal AC activity between the control group and melatonin-treated rats (Table 2).

Further experiments were carried out to explore the effect of melatonin on the functionality of Gi or Gs proteins in

Table 2

Effect of somatostatin (SRIF) $\left(10^{-4} \mathrm{M}\right)$ and forskolin (FK) $\left(10^{-5} \mathrm{M}\right)$ on brain adenylyl cyclase activity (pmol cAMP/min/mg protein) in hippocampal membranes from control and melatonin $(25 \mu \mathrm{g} / \mathrm{kg}$, s.c.)-treated rats for 4 days

\begin{tabular}{lcc}
\hline & Control & Melatonin \\
\hline Basal activity & $234.8 \pm 4.2$ & $263.0 \pm 5.9$ \\
$+10^{-4}$ M SRIF & $191.5 \pm 4.3$ & $236.6 \pm 6.2$ \\
$+10^{-5}$ M FK & $638.6 \pm 4.2$ & $634.7 \pm 10.9$ \\
$+10^{-5}$ M FK $+10^{-4}$ M SRIF & $515.0 \pm 17.1$ & $574.4 \pm 12.2$ \\
Fold FK stimulation over basal & $2.7 \pm 0.12$ & $2.4 \pm 0.08$ \\
\%SRIF inhibition of basal activity & $18.4 \pm 1.7$ & $10.0 \pm 1.8^{* *}$ \\
\%SRIF inhibition of FK stimulation & $18.8 \pm 3.7$ & $9.5 \pm 0.6^{*}$ \\
\hline
\end{tabular}

Values represent the mean \pm S.E.M. of five separate experiments, each performed in duplicate. Statistical comparison versus control: ${ }^{*} p<0.05$; ${ }^{* *} p<0.01$ 


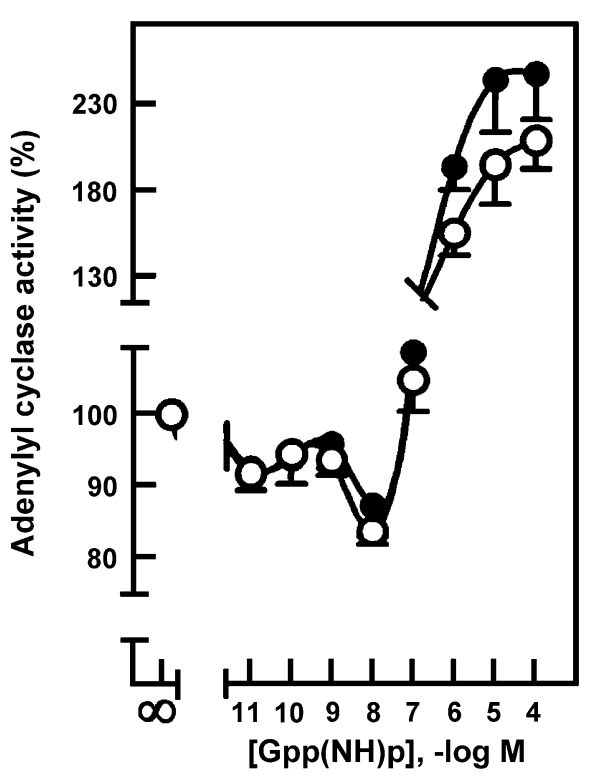

Fig. 3. Dose-effect curves for 5-guanylylimidodiphosphate [Gpp(NH)p]mediated inhibition of adenylyl cyclase activity in rat hippocampal membranes from control $(\mathrm{O}, n=5)$ and melatonin $(25 \mu \mathrm{g} / \mathrm{kg})$-treated $(\boldsymbol{\bullet}$, $n=5$ ) rats. The effect of Gpp(NH)p on adenylyl cyclase activity was studied in the presence of $3 \times 10^{-6} \mathrm{M}$ forskolin and the indicated concentrations of $\mathrm{Gpp}(\mathrm{NH})$ p. Data are expressed as a percentage of forskolin-stimulated adenylyl cyclase activity in the absence of Gpp(NH)p (100\%). The results are given as the mean \pm S.E.M. of five separate determinations, each performed in duplicate.

rat hippocampal membranes by determining the ability of low and high $\mathrm{Gpp}(\mathrm{NH}) \mathrm{p}$ concentrations to inhibit forskolin $\left(3 \times 10^{-6} \mathrm{M}\right)$-stimulated $\mathrm{AC}$ activity. Characteristic biphasic response curves were obtained in all the experimental groups. Gpp(NH)p concentrations ranging from $10^{-11}$ to $10^{-7} \mathrm{M}$ decreased $\mathrm{AC}$ activity due to Gi activation, whereas higher nucleotide concentrations $\left(10^{-6}-10^{-4} \mathrm{M}\right)$ resulted in stimulation of both $\mathrm{AC}$ and Gs activities. Hippocampal membranes from control and melatonin-treated rats showed similar functional activity Gi and Gs (Fig. 3).

In order to investigate whether the levels of the inhibitory

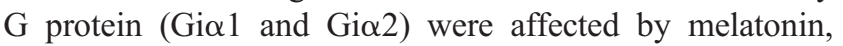
Western blot analyses were performed. Melatonin administration for 4, 7 or 14 days did not significantly alter the

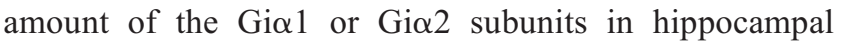
membranes (data not shown).

\section{Discussion}

The present study has examined the effects of short- and long-term melatonin $(25 \mu \mathrm{g} / \mathrm{kg}$, s.c.) administration on the rat hippocampal somatostatinergic system. Previous studies have shown that subcutaneous melatonin injection results in a rapid increase in the serum levels of this indol $30 \mathrm{~min}$ after its administration [26] and a gradual reduction in these levels 90 or $180 \mathrm{~min}$ later. Circulating melatonin passes the blood barrier and binds to its receptors, as demonstrated by systemic injection of radioactive melatonin in rodents $[13,44]$. A minimal dose of melatonin such as $25 \mu \mathrm{g} / \mathrm{kg}$ body weight during 4 days was enough to decrease both the SRIF-LI content in the rat hippocampus and the specific binding of $\left[{ }^{125} \mathrm{I}\right]-\mathrm{Tyr}{ }^{11}$-SRIF to rat hippocampal membranes as compared to the control group. The SRIF-LI content and equilibrium parameters of the SRIF receptors in the hippocampus of control rats were similar to those previously reported by others $[32,41]$.

Some of the responses induced by melatonin have been reported to be mediated via GABA-benzodiazepine receptors in the CNS $[24,29,38,45]$. Previous results from our group [19] suggest that melatonin via interaction with GABA receptors could modulate the rat hippocampal SRIFergic system. Thus, since melatonin inhibits GABA receptor function in the rat hippocampus [10] and GABA antagonists have been found to stimulate SRIF release [37], melatonin may lead to an increase in SRIF release and, therefore, to a decrease in SRIF content in the hippocampus as seen at 4 days of daily melatonin administration. An increased SRIF release might lead to a decrease in the density of the SRIF receptors in adjacent SRIF-containing neurons. Thus, regulation of SRIF receptors by SRIF appears to be similar to that of other hormone-receptor systems $[8,22]$.

Basal and forskolin-stimulated AC activity was inhibited by SRIF in all the experimental groups studied, which is in agreement with the literature [27]. A high concentration of SRIF $\left(10^{-4} \mathrm{M}\right)$ was required to produce this inhibition although the same concentration was used by other researchers in their studies on SRIF-mediated inhibition of $\mathrm{AC}$ activity in rat brain $[11,28]$. In a previous study from our group, the inhibitory effect of increasing SRIF concentrations on basal and forskolin $\left(10^{-5} \mathrm{M}\right)$-stimulated $\mathrm{AC}$ activity in control rats was analyzed [33]. SRIF-mediated inhibition of AC activity was only significant at the maximal concentration tested $\left(10^{-4} \mathrm{M}\right)$. Thus, this concentration was chosen for subsequent studies on AC activity. It should also be noted that abundant studies on the SRIF effect on AC activity were performed in cell lines expressing higher levels of SRIF receptors than in animal tissues. This may be due to the cell heterogeneity of the present preparations. Thus, SRIF inhibited basal AC activity in neuronal but not glial cells $[5,6]$. On the other hand, the synaptic concentration of SRIF is, to date, unknown. However, it is tempting to speculate that because the hippocampus is very rich in SRIF-containing neurons, the amount of SRIF released may be sufficiently great as to justify the high SRIF concentration used to inhibit AC activity. Therefore, it is possible that this concentration of SRIF is necessary to inhibit AC activity in our experimental conditions.

Melatonin administration led to a decrease in SRIFmediated inhibition of basal and forskolin-stimulated AC activity after a short-term 4-day daily administration. However, no changes were detected in either the basal or forskolin-stimulated AC activity, suggesting that the de- 
creased sensitivity of AC to SRIF inhibition was not due to an alteration of the $\mathrm{AC}$ catalytic subunit. Gi protein functionality, as measured by the capacity of $\mathrm{Gpp}(\mathrm{NH}) \mathrm{p}$ to inhibit forskolin-stimulated AC activity, was similar in both the melatonin-treated and control rats. On the other hand,

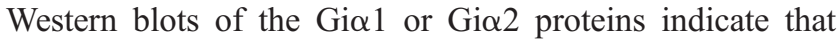
neither protein was modified by melatonin. Taken together, the present results suggest that the decrease in SRIF-mediated inhibition of AC activity is most probably due to the decrease in the number of SRIF receptors.

The melatonin-induced changes in the hippocampal SRIFergic system reversed to control values after 7 or 14 days of daily administration. This finding is in agreement with studies from Hadley [16], who demonstrated that continuous exposure to melatonin renders the target tissue unresponsive to the hormone. It has previously been reported that the total number of melatonin receptors in the hippocampal midbrain [30] and pars tuberalis of the anterior pituitary [17] may be reduced following prolonged exposure to melatonin.

Recently, Li et al. [24] have described that melatonin induces desensitization of the $\mathrm{GABA}_{\mathrm{A}}$ receptor. Several experiments indicate that there is a binding site for melatonin on the $\mathrm{GABA}_{\mathrm{A}}$ receptor $[29,38]$. Allosteric modulation of GABA receptors by melatonin was demonstrated in the rat brain [29]. This allosteric modulation provides a possible mechanism for regulating GABAergic transmission leading to desensitization of GABA receptors. Therefore, it is possible that a continuous exposure to melatonin via $\mathrm{GABA}_{\mathrm{A}}$ receptor desensitization causes the SRIF system to return to control values. In this regard, it should be noted that there are $\mathrm{GABA}_{\mathrm{A}}$ receptors located in hippocampal SRIF-containing neurons $[9,10]$ so that desensitization of $\mathrm{GABA}_{\mathrm{A}}$ receptors could blunt the release of SRIF which could explain the return of SRIF levels and SRIF receptors to control values.

The significance of the changes in the SRIF receptoreffector system induced by melatonin remains to be established. However, the fact that acute melatonin administration leads to a memory deficit is in agreement with the decrease of the SRIFergic system, which increases memory processes. In addition, the fact that memory deficits induced by melatonin revert to control values after chronic treatment with melatonin during 7 days [40] correlates with the return of activity to control values, as shown in this study. Therefore, the present results suggest that chronic exposure to melatonin results in tolerance of the rat hippocampus to this hormone.

\section{Acknowledgements}

We wish to thank Lilian Puebla for her excellent linguistic assistance and Mercedes Griera-Merino for her excellent technical assistance. This study was supported by grants from the Dirección General de Investigación del
Ministerio de Ciencia y Tecnología (PM99-0129) and the University of Alcalá (E007/97; E039/99), Spain.

\section{References}

[1] D. Acuña-Castroviejo, J.L. Castillo, B. Fernández, M.D. Gomar, C.M. Del Aguila, Modulation by pineal gland of ouabain high-affinity binding sites in rat cerebral cortex, Am. J. Physiol. 262 (1992) R698-R706.

[2] N.A. Alexiuk, J.P. Vriend, Melatonin reduces dopamine content in the neurointermediate lobe of male Syrian hamsters, Brain Res. Bull. 32 (1993) 433-436.

[3] J. Borjigin, X. Li, S.H. Snyder, The pineal gland and melatonin: molecular and pharmacological regulation, Annu. Rev. Pharmacol. Toxicol. 39 (1999) 53-65.

[4] B. Brzezinski, Melatonin in humans, N. Engl. J. Med. 336 (1997) $186-195$.

[5] H. Chneiweiss, J. Glowinski, J. Premont, Modulation by monoamines of somatostatin-sensitive adenylate cyclase on neuronal and glial cells from the mouse brain in primary cultures, J. Neurochem. 44 (1985) $1825-1831$

[6] H. Chneiweiss, J. Glowinski, J. Premont, Vasoactive intestinal polypeptide receptors linked to an adenylate cyclase and their relationship with biogenic amine and somatostatin-sensitive adenylate cyclase on central neuronal and glial cells in primary cultures, J. Neurochem. 44 (1985) $779-786$.

[7] A.J. Czernik, V. Petrack, Somatostatin receptor binding in rat cerebral cortex. Characterization using a nonreducible somatostatin analog, J. Biol. Chem. 285 (1983) 5525-5530.

[8] M.B. Davidson, S.A. Kaplan, Increased insulin binding to hepatic plasma membranes from diabetic rats: normalization by insulin therapy, J. Clin. Invest. 59 (1977) 22-30.

[9] M. Esclapez, D.K. Chang, C.R. Houser, Subpopulations of GABA neurons in the dentate gyrus express high levels of the alpha1 subunit of the $\mathrm{GABA}_{\mathrm{A}}$ receptor, Hippocampus 6 (1996) 225-238.

[10] B. Gao, J.M. Fritschy, Selective allocation of $\mathrm{GABA}_{\mathrm{A}}$ receptors containing the alpha1 subunit to neurochemically distinct subpopulations of rat hippocampal interneurons, Eur. J. Neurosci. 6 (1994) $837-853$.

[11] A. Garlind, C.J. Fowler, I. Alafuzoff, B. Winblad, R.F. Cowburn, Neurotransmitter-mediated inhibition of post-morten human brain adenylyl cyclase, J. Neural Transm., Gen. Sect. 87 (1992) 113-124.

[12] A.G. Gilman, A protein binding assay for adenosine $3^{\prime} 5^{\prime}$-cyclic monophosphate, Proc. Natl. Acad. Sci. U. S. A. 67 (1970) 305-312.

[13] M.S. Gitler, B.R. Zeeberg, C. John, R.C. Reba, Specific in vivo binding of $\left[{ }^{125} \mathrm{I}\right]$-iodomelatonin to melatonin receptors in rat brain, Neuropsychopharmacology 29 (1990) 603-608.

[14] J. Glowinski, L.L. Iversen, Regional studies of catecholamines in the rat brain: I. The disposition of $\left[{ }^{3} \mathrm{H}\right]$ norepinephrine, $\left[{ }^{3} \mathrm{H}\right]$ dopamine and $\left[{ }^{3} \mathrm{H}\right] \mathrm{DOPA}$ in various regions of the brain, J. Neurochem. 13 (1966) $655-669$.

[15] F.C. Greenwood, W.M. Hunter, J.S. Glover, The preparation of ${ }^{131} \mathrm{I}-$ labelled human growth hormone of high specific radioactivity, Biochem. J. 89 (1963) 114-123.

[16] M.E. Hadley, Endocrinology, second ed., Prentice-Hall, Englewood Cliffs, 1988.

[17] D.G. Hazlerigg, A. Gonzalez-Brito, W. Lawson, M.H. Hastings, P.J. Morgan, Prolonged exposure to melatonin leads to time dependent sensitization of adenylate cyclase and down-regulates melatonin receptors in pars tuberalis cells from ovine pituitary, Endocrinology 132 (1993) 285-292.

[18] M.D. Houslay, J.C. Metcalfe, G.B. Warren, T.R. Hesketh, G.A. Smith, The glucagon receptor of rat liver plasma membrane can couple to adenylate cyclase without activating it, Biochim. Biophys. Acta 436 (1976) $489-494$. 
[19] R.M. Izquierdo-Claros, M.C. Boyano-Adánez, M. Griera-Merino, L. Puebla, A. Ocaña, E. Arilla, Papel modulador de la melatonina sobre los niveles de inositol-1,4,5-trifosfato y sistema somatostatinérgico en el hipocampo de la rata, XXI Congreso de la Sociedad Española de Bioquímica y Biología Molecular (SEBBM), Sevilla, Spain, 1998, p. 263, Abstract.

[20] R.M. Izquierdo-Claros, M.C. Boyano-Adánez, E. Arilla-Ferreiro, Acutely administered melatonin decreases somatostatin-binding sites and the inhibitory effect of somatostatin on adenylyl cyclase activity in the rat hippocampus, J. Pineal Res. 36 (2004) 87-94.

[21] U.K. Laemmli, Cleaveage of structural proteins during the assembly of the head of bacteriophage T4, Nature 227 (1970) 680-685.

[22] M.A. Lesniak, J. Roth, Regulation of receptor concentration by homologous hormone. Effect of human growth hormone on its receptor in IM-9 lymphocytes, J. Biol. Chem. 251 (1976) 3720-3729.

[23] T.R. Levesque, W.L. Kenneth, Discriminative stimulus effects of melatonin in the rat, Psychopharmacology 116 (1994) 167-172.

[24] G.L. Li, P. Li, X.L. Yang, Melatonin modulates gamma-aminobutyric acid (A) receptor-mediated currents on isolated carp retinal neurons, Neurosci. Lett. 301 (2001) 49-53.

[25] O.H. Lowry, N.J. Rosenbrough, A.L. Farr, R.J. Randall, Protein measurement with the Folin phenol reagent, J. Biol. Chem. 193 (1951) $265-275$.

[26] A. Menendez-Pelaez, B. Poeggeler, R.J. Reiter, L. Barlow-Walden, M.I. Pablos, D. Tan, Nuclear localization of melatonin in different mammalian tissues: immunocytochemical and radioimmunoassay evidence, J. Cell. Biochem. 53 (1993) 373-382.

[27] W. Meyerhof, The elucidation of somatostatin receptor functions: a current view, Rev. Physiol., Biochem. Pharmacol. 133 (1998) $55-108$.

[28] M. Nagao, C. Sakamoto, T. Matozaki, H. Nishizaki, Y. Kondo, O. Nakano, S. Baba, Coupling of inhibitory GTP binding protein to somatostatin receptors on rat cerebrocortical membranes, Nippon Naibunpi Gakkai Zasshi 65 (1989) 1357-1366.

[29] L.P. Niles, C.H. Peace, Allosteric modulation of $t-\left[{ }^{35}\right.$ S $]$ butylbicyclophosphorothionate binding in rat brain by melatonin, Brain Res. Bull. 24 (1990) 635-638.

[30] S. Oaknin-Bendahan, Y. Anis, I. Nir, N. Zisapel, Pinealectomy but not melatonin supplementation affects the diurnal variations in ${ }^{125} \mathrm{I}$-melatonin binding sites in the rat brain, J. Basic Clin. Physiol. Pharmacol. 3 (1992) 253-268.

[31] Y.C. Patel, S. Reichlin, Somatostatin in hypothalamus, extrahypothalamic brain, and peripheral tissues of the rat, Endocrinology 102 (1978) 523-530.
[32] A. Pitkanen, J. Sirvio, J. Jolkonnne, P. Reikkinen, Somatostatin-like immunoreactivity and somatostatin receptor binding in rat brain before and after pentylenetetrazol induced convulsion, Neuropeptides 7 (1986) 63-71.

[33] L. Puebla, E. Arilla, Involvement of presynaptic histamine $\mathrm{H}_{3}$ receptors in the modulation of somatostatin binding and its effects on adenylyl cyclase activity in the rat frontoparietal cortex, J. Neurochem. 66 (1996) 1051-1059.

[34] G.L. Ralph, Melatonin production by extra-pineal tissues, in: N. Birau, W. Schjiloot (Eds.), Melatonin: Current Status and Perspectives, Pergamon, New York, 2003, pp. 35-46.

[35] R.J. Reiter, L. Tang, J.J. Garcia, A.M. Hoyos, Pharmacological actions of melatonin in oxygen radical pathophysiology, Life Sci. 60 (1997) 2255-2271.

[36] J.C. Reubi, M.H. Perrin, J.E. Rivier, W. Vale, High affinity binding sites for a somatostatin-28 analog in rat brain, Life Sci. 28 (1981) 2191-2198.

[37] R. Robbins, R.M. Landon, Somatostatin release from cerebral cortical cells: influence of amino acid neurotransmitters, Brain Res. 273 (1983) 374-379.

[38] R.E. Rosenstein, H.E. Chuluyan, M.C. Diaz, D.P. Cardinali, GABA as a presumptive paracrine signal in the pineal gland. Evidence on an intrapineal GABAergic system, Brain Res. Bull. 25 (1990) $339-344$.

[39] G. Schettini, T. Florio, O. Meucci, E. Landolfi, M. Grimaldi, C. Ventra, A. Marino, Somatostatin inhibition of adenylate cyclase activity in different brain areas, Brain Res. 492 (1989) 65-71.

[40] A.V. Shaji, S.K. Kulkarni, Evidence of GABAergic modulation in melatonin-induced short-term memory deficits and food consumption, Methods Find. Exp. Clin. Pharmacol. 20 (1998) 311-319.

[41] C.B. Srikant, Y.C. Patel, Somatostatin receptors: identification and characterization in rat brain membranes, Proc. Natl. Acad. Sci. U. S. A. 78 (1981) 3930-3934.

[42] S. Steinlechner, Melatonin as a chronobiotic: PROS and CONS, Acta Neurobiol. Exp. 56 (1996) 363-372.

[43] J. Vanecek, Cellular mechanisms of melatonin action, Physiol. Rev. 78 (1998) 687-721.

[44] P.A. Vitte, C. Harthe, C. Pevet, B. Claustrat, Brain autoradiographic study in the golden hamster after intracarotid injection of $\left[{ }^{14} \mathrm{C}\right]$ melatonin, Neurosci. Lett. 110 (1990) 1-5.

[45] Q. Wan, H.Y. Man, F. Lin, J. Braunton, H.B. Niznik, S.F. Pang, G.M. Brown, Y.T. Wang, Differential modulation of $\mathrm{GABA}_{\mathrm{A}}$ receptor function by Mella and Mellb receptors, Nat. Neurosci. 2 (1999) 401-403. 